\title{
THE IMMUNITY OF SAN FRANCISCO RATS TO INFECTION WITH B. PESTIS.*
}

GEORGE W. MCCOY.

Passed Assistant Surgeon, United States Public Health and Marine Hospital Service.

ExPERIMENTs undertaken for the purpose of ascertaining the influence upon the virulence of $B$. pestis by passage from rat to rat without intermediate culture on artificial media showed that a certain number of the wild rats (Mus norvegicus) in San Francisco were immune to plague infection. This result led me to undertake a series of experiments to determine the extent of this immunity.

The Indian Plague Commission ${ }^{1}$ found that 59 per cent of the wild rats of Bombay were immune when inoculated by the cutaneous method with splenic material containing a large number of $B$. pesits. They also found a certain percentage of the rats immune to subcutaneous inoculation of agar culture of $B$. pestis. The smallest dose of plague culture used by the Indian Commission in their work was $\frac{1}{2} 50$ part of an agar culture. This immunity varied from 3.7 per cent to I0. 5 per cent, depending upon the amount of culture injected. They note that other writers had previously observed the immunity of wild rats to plague infection.

It is somewhat difficult to determine just what constitutes complete immunity in the case of animals in which careful clinical observation is impracticable, as it is very evident that an animal may have a slight infection of which no trace remains when it is examined a week or Io days after the inoculation. It was assumed in my work that a rat that had not died by the eighth day would not die of acute plague, and that the lesions of chronic plague would be sufficiently developed to offer no difficulty of diagnosis.

The diagnosis of acute plague was based upon the gross lesions observed at post mortem, and in a few cases where the gross lesions were not sufficiently characteristic, cultures were made, and $B$. pestis isolated. The lesions of chronic plague, a caseous or purulent lym-

* Received for publication April I7, 1909.

I Jour. of $H y g$., Igo6, 6, p. 422. 
phatic gland alone or associated with large caseous foci in the spleen, or such foci in the spleen without other lesions, offer more difficulty in diagnosis. Some of the cases diagnosed as chronic plague have been verified by inoculation into a guinea-pig of the material from the bubo or the spleen. In the other cases, the diagnosis has been based upon the gross lesions alone. I may remark here that in the examination of considerably over 100,000 rats in San Francisco, no case that could be proven to be chronic plague due to natural infection has been encountered, and out of all those examined not more than half a dozen rats have been seen presenting lesions strongly suggestive of chronic plague as we have observed it in inoculated rats.

It is, of course, very evident that results in an investigation of this sort will depend very largely on the virulence of the organism used. For this work, when cultures were employed we have used only those known to be highly virulent. The tissues used are known to have been capable of producing acute plague which was invariably fatal in all of the guinea-pigs and all of the white rats that were inoculated.

I am unable to say exactly what influence the size of the dose (aside from overwhelmingly large doses) of culture inoculated has in determining whether infection in the rat will take place or not. It is evident that the existence of natural immunity among animals makes it very difficult to determine this point. There is practically no natural immunity to plague infection among guinea-pigs and in these animals the size of the dose of culture used is a matter of but little consequence. Indeed it happens not infrequently that a guineapig having received a certain amount of culture of $B$. pestis will die earlier than one having received a very much larger dose of the same culture.

The only experimental evidence bearing on this point in reference to the wild rats of San Francisco is as follows: A culture from natural plague Rat 64 , third generation on agar, was used to inoculate subcutaneously four medium-sized rats (Mus norvegicus).

It will be seen here that Rat 2, which survived, received a dose of culture Ioo times as great as that given Rat 4, which died on the fifth day with lesions of acute plague. B. pestis was isolated from 
the liver of Rat 4. Rat 2 was killed on the ninth day and was found to be entirely normal except for an enlarged spleen. Cultures from the spleen remained sterile. I am disposed to believe that this animal had suffered from a mild infection from which it was recovering, the enlarged spleen being the only remaining evidence of the contest between the bacteria and the defensive agencies of the body.

TABLE $\mathbf{~}$.

\begin{tabular}{|c|c|c|c|c|}
\hline & $\begin{array}{c}\text { Weight of Rats } \\
\text { Gm. }\end{array}$ & Dose of Cultur & Tsed & Result \\
\hline 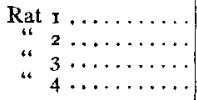 & $\begin{array}{l}175 \\
155 \\
185 \\
175\end{array}$ & 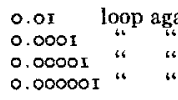 & $\begin{array}{l}\text { ulture } \\
" ، \\
"\end{array}$ & $\begin{array}{l}\text { Died 4th day of acute plague } \\
\text { Killed oth day; enlarged spleen only } \\
\text { Died 8th day of subacute plague } \\
\text { Died 5th day of acute plague }\end{array}$ \\
\hline
\end{tabular}

Very large doses of culture frequently kill the animals early without producing characteristic lesions of plague infection.

In the early part of my work it was observed that the older rats were much less susceptible to infection than the younger ones; therefore, whenever practicable a record was made of the weight of each animal at the time of inoculation, and as will be seen throughout the tables, the percentage of immunity is much higher in old (large) rats than in young (small) ones.

Technic.-Our inoculated rats were kept in speciaily constructed insect-proof cages, and under such conditions that there was practically no natural mortality among them. Occasionally a rat died in the cage from some cause other than plague, but this was very exceptional. When the subcutaneous method of inoculation was used, the suspension of the culture in physiological salt-solution was injected in the usual manner under the skin of the abdomen. When the cutaneous method was employed, the skin of the belly was shaven dry, and care was always taken to abrade the epithelium, leaving a raw surface. The culture was rubbed into the raw surface with a platinum loop, or if tissue was used it was vigorously rubbed on the abraded area.

The record of the experiments will be arranged here under the head of the species of rats used.

\section{Mus alexandrinus.}

We have been able to secure but one of this species alive. This specimen weighed $70 \mathrm{gm}$. and was inoculated subcutaneously with $\mathrm{I} / \mathrm{I} 00$ of a loop of an agar culture of $B$. pestis which had been isolated about eight months previously. The animal died on the fourth day and presented the typical lesions of plague. A culture of $B$. pesis was isolated from the liver. A guinea-pig control also died on the fourth day with typical lesions of plague.

\section{Mus rattus.}

Comparatively few rats of this species have been available for this work. The following table shows the results of the experiments in tabular form. 
TABLE 2

\begin{tabular}{|c|c|c|c|c|c|c|c|}
\hline \multirow{2}{*}{$\begin{array}{l}\text { MATERIAL USED FOR INOCU- } \\
\text { LATION }\end{array}$} & \multirow{2}{*}{$\begin{array}{l}\text { DOSE AND MODE } \\
\text { OF INOCULATION }\end{array}$} & \multirow{2}{*}{$\begin{array}{l}\text { No. } \\
\text { RATS } \\
\text { USEO }\end{array}$} & \multirow{2}{*}{$\begin{array}{c}\text { WEIGHT } \\
\text { GMI. }\end{array}$} & \multicolumn{4}{|c|}{$\begin{array}{l}\text { Dien of Acute Plague } \\
\text { Day of Death }\end{array}$} \\
\hline & & & & 3 & 4 & 5 & 6 \\
\hline 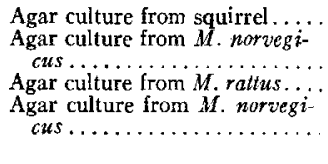 & $\begin{array}{l}0.01 \text { loop subcut. } \\
0.01 \text { " } 01 \\
0.01 \text { " } \\
\text { I " }\end{array}$ & $\begin{array}{l}3 \\
2 \\
2 \\
\mathbf{I}\end{array}$ & $\begin{array}{l}\text { All small } \\
90^{-} ? \\
\text { 105-250 } \\
\text { Large }\end{array}$ & $\begin{array}{l}\cdots \\
.\end{array}$ & I & I & $\begin{array}{c}\cdots \\
\mathbf{I} \\
\cdots\end{array}$ \\
\hline
\end{tabular}

It will be observed that of the eight rats used all died of acute plague excepting one which was killed on the ninth day after inoculation and found to have chronic plague. A guinea-pig inoculated from the spleen of this rat died of acute plague.

The cultures used had all been isolated directly from naturally infected animals. The squirrel and the Mus rattus cultures were only a few days old. The Mus norvegicus cultures were about five months old. The number of rats used was not large enough to enable one to draw any conclusions, but no example of absolute immunity was encountered. The case of chronic plague may perhaps be regarded as an example of partial immunity.

\section{Mus norvegicus.}

The first experiments were with material derived directly from cases of natural plague. The spleen from a case of human plague was used to inoculate two rats by the cutaneous method. One died on the seventh day and was found to present lesions of acute plague; the other (the larger) was killed on the seventh day and found entirely normal.

Three medium-sized rats were inoculated by the cutaneous method with the spleen of a natural plague rat. One died on the fifth day, one on the sixth; both showed the lesions of acute plague; the third, when killed on the ninth day, was found to present the lesions of chronic plague.

Three grown rats were inoculated subcutaneously with an emulsion of the spleen from a plague rat (a pure culture of $B$. pestis was isolated later from the spleen). One died of typical plague on the third day. The other two were killed on the sixth day. One showed a local abscess at the site of inoculation; cultures from the spleen remained sterile. The third showed a caseous bubo only in one groin. The bubo was used to inoculate a guinea-pig by the cutaneous method. The guinea-pig died of acute plague on the sixth day.

Control guinea-pigs and white rats were inoculated in each case with the same material used to inoculate the wild rats. These controls all died of acute plague.

The next experiment extended over a period of about four months. The culture used was one isolated on June 30 , 1908 , directly from the liver of a natural plague rat. It had never been passed through a laboratory animal. This culture is very virulent or guinea-pigs and white rats. The fifth generation on agar was kept as a stock culture and from this a subculture was made when we wished to inoculate a series of rats so that each series was inoculated with the sixth generation of this culture. The platinum loop used was one that was estimated to be capable of taking up $260,000,000 \mathrm{~B}$. pestis rom an agar culture. One ten-millionth part of this loopful of culture injected sub- 
cutaneously killed in eight days a guinea-pig weighing over $300 \mathrm{gm}$. The dose used for the rats in these experiments was 100,000 times as great.

A 24-hour culture was used except in the series inoculated on October I2, when a five-day-old culture was used.

TABLE 3.

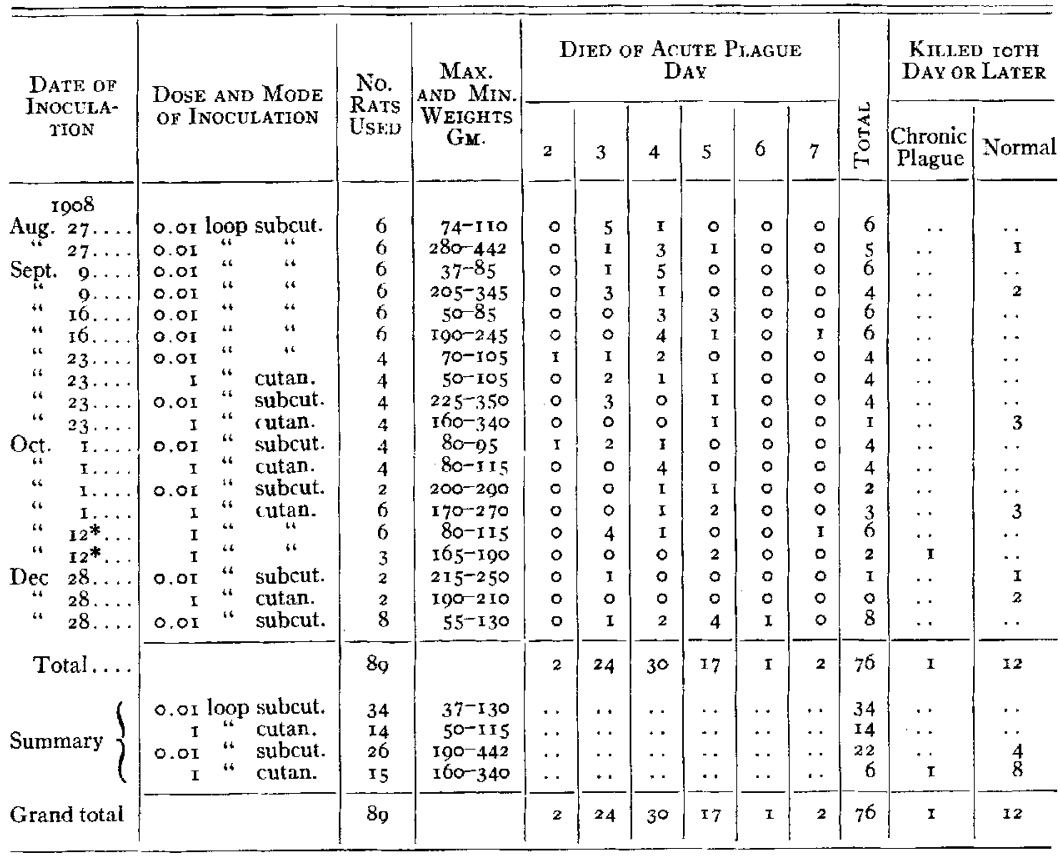

* Five-day-old culture.

A number of rats have been inoculated by the cutaneous method from the tissues of squirrels infected experimentally with plague. The material used for inoculation always showed large numbers of pest-like organisms. Guinea-pig controls were inoculated at the same time and in the same manner as the rats, one guinea-pig being used for every three rats. The controls all died of acute plague. The results are shown in the following table:

TABLE 4

\begin{tabular}{|c|c|c|c|c|c|c|c|}
\hline & \multirow{2}{*}{$\begin{array}{l}\text { No. } \\
\text { USED }\end{array}$} & \multicolumn{4}{|c|}{$\begin{array}{c}\text { Died of Acute Plague } \\
\text { Day OF DEATH }\end{array}$} & \multirow{2}{*}{$\begin{array}{l}\text { DIED OF CHRONIC } \\
\text { PLAGUE OR FOUND } \\
\text { SUEFERING FROM } \\
\text { SAME WHEN KILLED }\end{array}$} & \multirow{2}{*}{$\begin{array}{c}\text { KILLEI IOTH DAY } \\
\text { OR LATER; } \\
\text { No LESIONS }\end{array}$} \\
\hline & & 4 & 5 & 6 & 7 & & \\
\hline $\begin{array}{l}\text { Rats weighing under } \\
\text { } 25 \mathrm{gm} . . . \ldots \ldots \\
\text { Rats weighing over } \\
200 \mathrm{gm} . \ldots \ldots \ldots \ldots\end{array}$ & $\begin{array}{r}27 \\
3\end{array}$ & . & $\cdots$ & 3 & $\begin{array}{l}3 \\
\cdots\end{array}$ & I & $\begin{array}{l}6 \\
\mathbf{I}\end{array}$ \\
\hline
\end{tabular}

Sixteen small rats and eight large ones were inoculated by the cutaneous method with the spleen of a guinea-pig dead of typical acute plague on the seventh day after inoculation with material from an artificially infected squirrel. The smears from the 
spleen showed large numbers of typical B. pestis and a pure culture of the organism was isolated from it. The results were as follows:

TABLE 5

\begin{tabular}{|c|c|c|c|c|c|c|c|}
\hline & \multirow{2}{*}{$\begin{array}{l}\text { No. } \\
\text { USED }\end{array}$} & \multicolumn{4}{|c|}{$\begin{array}{l}\text { Died of Acute Plague } \\
\text { Day of Death }\end{array}$} & \multirow{2}{*}{$\begin{array}{l}\text { Chronic Plague; } \\
\text { DIED AFTER 9TH } \\
\text { DAY OR LESIONS } \\
\text { FOUND WHEN } \\
\text { KILLED ON I4TH } \\
\text { DAY }\end{array}$} & \multirow{2}{*}{$\begin{array}{l}\text { KILLED ON I4TH } \\
\text { DAY; NO LESIONS }\end{array}$} \\
\hline & & 4 & 5 & 6 & 7 & & \\
\hline $\begin{array}{l}\text { Rats weighing under } \\
\text { 120 gm........... }\end{array}$ & 16 & I & 2 & I & 2 & 4 & 6 \\
\hline $\begin{array}{l}\text { Rats weighing over } \\
295 \mathrm{gm.} . \ldots \ldots \ldots\end{array}$ & 8 & 0 & 0 & 0 & 0 & 2 & 6 \\
\hline
\end{tabular}

A number of rats have been inoculated by the cutaneous method from rats artificially infected with plague. Unfortunately no accurate record was made of the weight of the animals inoculated; they are simply classified as large, small, and medium. The results are as follows:

TABLE 6

\begin{tabular}{|c|c|c|c|c|c|c|c|c|c|}
\hline & \multirow{2}{*}{$\begin{array}{l}\text { NUMBER } \\
\text { INOCU- } \\
\text { LATED }\end{array}$} & \multicolumn{6}{|c|}{$\begin{array}{c}\text { Died of Acute Plague } \\
\text { Day OF Death }\end{array}$} & \multirow{2}{*}{$\begin{array}{l}\text { Chronic } \\
\text { Plague }\end{array}$} & \multirow{2}{*}{$\begin{array}{l}\text { No } \\
\text { LESIONS }\end{array}$} \\
\hline & & 2 & 3 & 4 & 5 & 6. & 7 & & \\
\hline $\begin{array}{l}\text { Large rats } \ldots \ldots \ldots \ldots \ldots \ldots \ldots \\
\text { Medium-sized rats } \ldots \ldots \ldots \ldots \\
\text { Small rats. . . . . . } \ldots \ldots \ldots \ldots\end{array}$ & $\begin{array}{r}12 \\
9 \\
5\end{array}$ & $\begin{array}{l}\cdots \\
\mathbf{I} \\
\cdots\end{array}$ & $\begin{array}{l}I \\
3 \\
\cdots\end{array}$ & $\begin{array}{l}\mathbf{2} \\
\mathbf{I} \\
\mathbf{I}\end{array}$ & $\begin{array}{l}3 \\
2 \\
\mathbf{I}\end{array}$ & $\begin{array}{l}\cdots \\
\cdots\end{array}$ & $\because$ & $\begin{array}{l}4 \\
\cdots \\
\cdots\end{array}$ & $\begin{array}{l}2 \\
\mathbf{I} \\
\mathbf{I}\end{array}$ \\
\hline
\end{tabular}

Combining the figures in the last three tables, which may properly be done as the conditions were similar, we find that the results are as follows:

TABLE $\%$.

\begin{tabular}{|c|c|c|c|c|}
\hline & No. Used & Acute Plague & Chronic Plague & No Lesions \\
\hline $\begin{array}{l}\text { LaRge Rats } \\
\text { Table } 4 \ldots \ldots \ldots \ldots \\
\text { Table } 5 \ldots \ldots \ldots \ldots \\
\text { Table } 6 \ldots \ldots \ldots \ldots\end{array}$ & $\begin{array}{r}3 \\
8 \\
12\end{array}$ & $\begin{array}{l}\text { I } \\
0 \\
6\end{array}$ & $\begin{array}{l}\text { I } \\
2 \\
4\end{array}$ & $\begin{array}{l}I \\
6 \\
2\end{array}$ \\
\hline 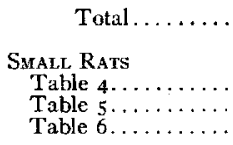 & $\begin{array}{r}27 \\
16 \\
5\end{array}$ & $\begin{array}{l}7(30+\text { per cent }) \\
19 \\
6 \\
4\end{array}$ & $\begin{array}{l}7 \text { (30+ per cent }) \\
2 \\
4 \\
0\end{array}$ & $\begin{array}{l}9(39+\text { per cent }) \\
6 \\
6 \\
1\end{array}$ \\
\hline Total........ & $4^{8}$ & $29(60+$ per cent $)$ & 6 (I2.5 per cent) & $\mathbf{r}_{3}(27+$ per cent $)$ \\
\hline
\end{tabular}

The immunity demonstrated in these experiments $I$ regard as natural and not as acquired, for the following reasons:

First, the percentage of immunity in old rats is so high as to preclude the possibility of a previous attack of plague in these cases. The natural plague infection among San Francisco rats has never excceded 2 per cent and this high percentage existed for a very short time only. 
Second, a considerable percentage of immunity to inoculation by the cutaneous method was found in rats that were certainly not more than two or three months old. These rats were used six months after the epizootic had terminated. In other words, an immunity was found among rats that we know positively had never been exposed to an epizootic of plague.

\section{SUMMARY.}

A considerable immunity to plague infection exists among the wild rats of San Francisco. The percentage of immunity is especially high among the old rats.

The immunity encountered is probably natural in most cases, not acquired.

NoTE.--The three species of rats may readily be distinguished by attention to the following points:

Mus norvegicus (Norway rat, sewer rat, gray rat; until recently known as $M u$ s decumanus).-This constitutes about 98 per cent of the total rat population of San Francisco. The color is gray or brownish. The under surface of the body is usually gray or grayish brown, but occasionally it will be almost pure white. At times specimens are encountered in which large, pure white spots are found on the abdomen. The head is short and broad. The ears are rather short. The tail is shorter than the head and the body together.

Mus rattus (black rat, house rat, ship rat).-This species is usually smaller than Mus norvegicus. The color is black, sometimes with a grayish tinge. The belly is usually black, but sometimes white. The head is more pointed than in $M$ us norvegicus. The ears are much larger and more delicate than those of Mus norvegicus. The tail is longer than the head and the body together.

Mus alexandrinus.- This rat is regarded by some writers as merely a variety of Mus rallus. It is often spoken of as the roof rat or tree rat. It resembles $M$ us rattus rather closely except in color, which is grayish red or rusty. The belly is pure white. The tail is always longer than the head and body.

A good many specimens are encountered in which there is difficulty in distinguishing Mus alexandrinus from $M$ Ms rattus, but $M$ us norvegicus is not likely to be confused with either of the other species. We have seen no specimen that we had any reason for considering a hybrid. 